\title{
遺伝的アルゴリズムによるマルチカーエレベータ制御ルールの シミュレーションベースド最適化
}

\author{
鈴 木 裕 通*·高橋聡**.佐 野 泰 仁 ${ }^{* * *}$

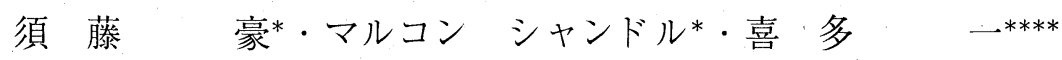

Simulation-based Optimization of Multi-Car Elevator Controllers Using a Genetic Algorithm

\author{
Hiromichi Suzuki*, Satoshi TaKahashi* ${ }^{* *}$, Yasuhito SANO***, \\ Takeshi SUdO*, Sandor MARKON* and Hajime KITA ${ }^{* * * *}$
}

\begin{abstract}
Recent progress in linear motor and mechanical technologies shows the possibility of constructing multi-car elevators (MCE) that have several elevator cars in a single shaft. While remarkable improvement of performance of vertical transportation in high-rise buildings is expected with MCE, we have to develop not only the hardware of MCE but also a control strategy for them to achieve such expectation. Because of the complexity of MCE, applicability of control techniques for conventional elevators to the MCE is limited, and we need to start the research of control strategy from scratch. This paper discusses development of controllers for MCE through simulation-based optimization using a genetic alrogithm. First, a simulator of MCE that has sufficient precision to discuss realistic MCE is developed. Second, the effect of a simple control strategy for MCE is examined with the developed simulator. Finally, a genetic algorithm is applied to refine the control strategy of MCE through simulation-based optimization.
\end{abstract}

Key Words: simulation-based optimization, genetic algorithm, multi-car elevator

\section{1.はじめに}

高層ビル内での垂直移動には，もっぱらエレベータが使用 される. 従来のエレベータでは「かご」をロープで吊してい るため運搬可能な高さと量に限界がある. 前者はロープの強 度に起因し，ロープの強度がそれ自身の自重とかごとを支え られなくなる限界のロープ長は, 工学的に実現可能な建造物 の高さと同程度である．後者はエレベータ・シャフトあたり の運搬可能な輸送量に起因する.シャフトが長くなると, か ごが最下階から最上階までの往復に要する時間が長くなり, シャフトあたりの輸送能力が低下する。この点については従 来, シャフト数の増加で対応してきた. しかし, エレベータ はビル床面積の多くの割合を占める構造物であるため, この 対応にも限界がある.シャフトあたりの輸送能力を向上させ るために, シャフト内にロープ式のかごを 2 台設置された

\footnotetext{
* フジテック（株） 茨木市庄 1-28-10

** 富士重工業（株） 三鷹市大沢 3-9-6

*** 日産自動車（株）横須賀市夏島 1

**** 京都大学 京都市左京区吉田二本松町

* Fujitec Co., Ltd.

** Fuji Heavy Industries Ltd.

*** Nissan Motors Co., Ltd

**** Kyoto University (Received October 24, 2003)
}

エレベータの実用化 ${ }^{3)}$ も行なわれている.しかし，ロープ を用いる制約により，さらなるかごのシャフトへの追加は物 理的に困難であり, 対応可能な建造物の規模には同様の限界 がある。

運搬可能な高さと量に対する限界への対策として, リニア モーターによりかごを上下に駆動するエレベータの研究が行 なわれている ${ }^{6)}$.この方式では原理的にロープが不要となる ため, 先述の高さに関する制約がなくなる．また，シャフト 内に多数のかごを配置することも可能であり，シャフトあた りの運搬能力の改善も期待できる. 以後, リニアモーターの 利用を想定して 1 つのシャフト内に複数のかごを設けたエ レベータを，マルチカーエレベータ（Multi-Car Elevators） と呼び, MCEと略記する.

MCE による運搬能力の改善を図るためは，ハードウェア だけではなく，その制御方法の開発も求められる。 MCEに ついては, その運行制御は未経験である. 同一シャフト内で のかご同士の衝突を避ける必要性など, MCE 特有の種々の 制約が存在するため, 従来のエレベータの群管理制御の知 見を単純に MCEに利用することはできない.したがって， $\mathrm{MCE}$ 固有の制約を考慮しつつ効率的な輸送を実現する運行 制御手法の開発が必要である.

本論文では，MCEの運行制御について，そのシミュレー 
ションを基礎とした制御ルールの検討を行なった。まず，運 行制御の評洒に十分な精度を備えたシミュレータを作成し た。つぎに，MCEの基本的な性能の評価のために，経験的 手法で制御方式を構成し, MCEの導入効果の評価をシミュ レーションにより行なった。ささらに, 遺伝的アルゴリズムに よる MCEの運行制御ルールの最適化について検討した。

2. マルチカーエレベータシステム

\section{1 システムの概要}

MCEの主な構成要素を以下に挙げる：

・ビルの入りロがあり交通量の多い夕ーミナル階.

・ターミナル階でないビルの一般階.

・乗客を輸送するかご。

・エレベータかごが上下移動する空間を提供するシャフト. MCEの構成についてはかごの水平移動が可能であること を想定したシステム4),5) や, 垂直移動のみのシステム ${ }^{4)}$ が ある. かごの水平移動を可能とすると, 退避追い越しが可 能となり制御の柔軟性が高まる。たとえば，文献 4)，5)で はかごが回送用のシャフトへ水平移動することで衝突回避 を行なっている.しかし，この種の MCE 構成はハードウェ アの実現が難しく, 安全装置, 保守性および乗り心地の問題 も生じる。一方, 水平移動を考えない場合はハードウェアの 実現が容易になる。しかし，かごによってはサービスを行な えない階が生じたり，衝突回避の制約が生じたりするため， 運行制御は水平移動が可能な場合に比べて困難になる。ま た, 乗客を特定のかごへ適切に誘導することも必要となる. 文献 6) ではすべてのかごを最下のターミナル階にサービス させるために，下方のかごを退避させるガレージ階を設けて いる。

本論文ではハードウェアの実現性の高い後者の MCE の構 成について運行制御を検討する. 以下, 具体的な構成を述べ る (Fig. 1 参照)：

かご それぞれのかごは自身に搭載されたリニアモーター式

駆動装置により, 上下方向のみ移動のみ可能であるとし, かごのシャフト間の移動は考えない.

ガレージ階の導入 本システムでは, すべてのかごが最下階 のターミナル階でサービスを行なうことを想定している. その際, 最下階の下側にガレージ階を設けて，上かごの ターミナル階でのサービスのために, 下かごをガレージ 階に退避させる。ただ，乗客の利用頻度が低く，また， ビルの高さをより高くしてしまうことから，最上階の上に はガレージ階を設けない.

ゾーン型運行 衝突回避および各かごの運行を容易にする ため, ビルの階床をゾーンに分割し，かごがサービスする ゾーンをあらかじめ割り当てておくゾーン運転を導入す る。従来の超高階移動を行なうエレベータシステムでは, シャフトごとにサービス可能な階床を区切ってゾーン運転 を行なっている。これに対し本システムでは, 同一シャフ ト内にゾーン区切りを設け，区切られたゾーンを各かごに

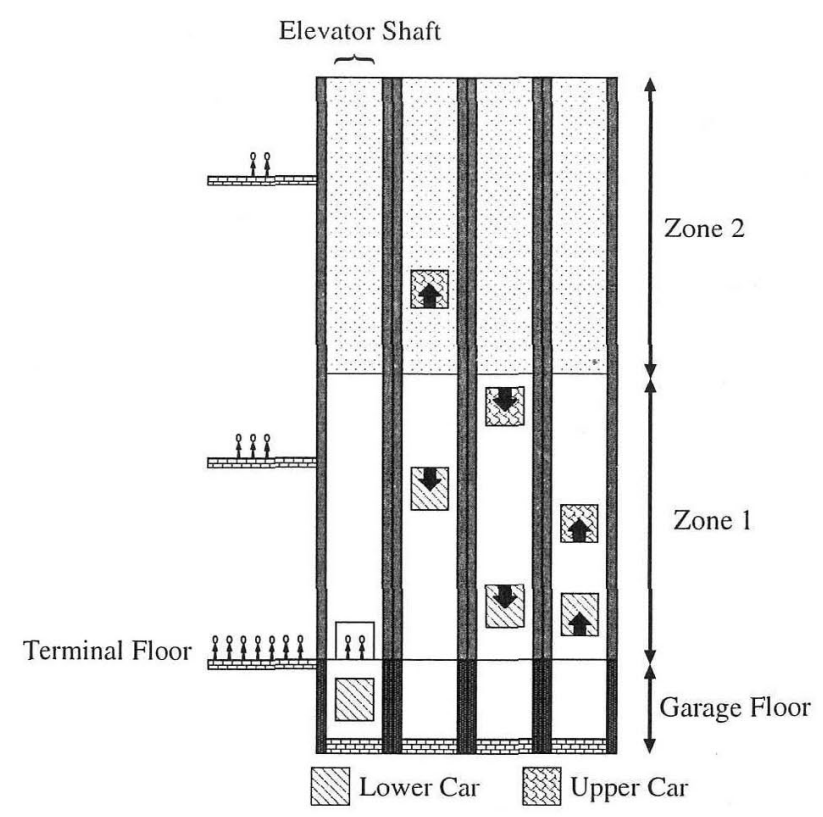

Fig. 1 Proposed multicar elevator system

分担させ，かごは担当するゾーン内の乗客にサービスを行 なう.

衝突回避 本システムでは, あるかごが目的階へ移動する場 合に，移動の妨げとなっているほかのかごを上か下に移動 させることで衝突回避を行なう。

乗場行先階登録 本システムでは乗客がエレベータの呼び (ホール呼び) を行なう際, 一般的に用いられている上下 方向のみの登録ではなく, 行先階を指定することを想定し ている。これは, 同一シャフトでもかごによってサービス 可能なゾーンが異なっており, 登録した乗客を対応するか ごへ誘導する必要があるためである。

\section{3. 運行制御の検討方法}

MCE については同一シャフト内のかごの衝突回避など制 約条件が従来の群管理制御のエレベータとは異なっている. このため, その制御方式については基礎的な段階から検討を 行なう必要がある。本論文では以下に挙げる手順で研究を進 めた：

(1) MCE シミュレータの構築.

（2）基本的な制御ルールによる $\mathrm{MCE}$ の性能評価.

（３）遺伝的アルゴリズムによる制御ルールの最適化.

\section{4. $\mathrm{MCE}$ シミュレータの構築}

MCE の運行制御の検討に際し, 十分なモデル化能力, 精 度，および実行速度を有した MCEシミュレータを開発した。 このシミュレータは, ビル内交通用の離散事象シミュレー タ77,8) 上に MCEをモデル化したものである.このシミュ レータは以下に挙げる特徴を有している：

・乗客やエレベータのかごの動作をそれぞれ有限状態 オートマトンに準じた Extended State Machine（以下, 
ESM $)^{9)}$ として記述する ${ }^{7)}$.

・シミュレーションの各ステップを任意の時間間隔とした

離散事象シミュレーションが可能である。

・ESM で記述されるかごや乗客などのオブジェクトの相 互作用は ESM 間のメッセージ送受信によりモデル化さ れる。

・個々の乗客によるホールボタンの押下, かごの乗降もシ ミュレーショシされる．乗客を表わす ESM は,「ストレー ジ」機構 ${ }^{8)}$ で管理され，シミュレーション中に生成／接 続／消滅される。

・ESM でモデル化されたシミュレータは最終的に Java 言語に変換されて実行される。

MCEのモデル化については，以下に挙げる ESM とスト レージからなるモデルを構成した：

・呼びボタンを押し，エレべータの到着を待ち，かごへの 乗り降りを行なう乗客の ESM.

・かごの走行を行なう ESM.

・扉の開閉を行なう ESM.

・ホール待ちの乗客を保持するストレージ.

・乗車中の乗客を保持するストレージ.

・乗客を生成／消滅を行なうストレージ.

また，シミュレータを構築する際に以下の 3 つの階層を導 入し，運行制御の記述性の向上を図った：

- MCEの物理的動作のシミュレーション.

- $\mathrm{MCE}$ の運行制御機構のシミュレーション.

・制御方式のパラメータのシミュレーションベースの評価 と最適化.

\section{MCE の基本的制御性能の確認}

5.1 シミュレータと MCEの性能確認の目的とその方法 $\mathrm{MCE}$ の運行制御の検討に際し，シミュレーションの精度 と実行速度について確認する必要がある。また，MCEの動 作上の問題をシミュレーションを通じて把握する必要もあ る. そこで, 性能の評価基準を得るために単純な制御ルール を用いたシミュレーションを行なった。 また，最適化手法の 適用において実行可能なシミュレーション回数を把握するた め, シミュレータの速度についても確認を行なった。 MCE シミュレータの確認は以下の手順で行なった：

（1）性能評価の基準となるモデル環境の設定.

（2）想定した環境における MCEの性能評価.

（3）運行線図による MCEの挙動の妥当性の確認.

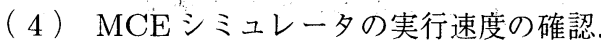

5.2 モデル MCE シミュレーションの設定

MCE のシミュレーションに際して，ビルやかごおよび乗 客の仕様, 交通需要, 設備構成, 制約条件, 制御ルールなど を設定する必要がある，以下；各設定について述べる。

5.2 .1 ビルやかごおよび乗客の仕様

MCE の基本的な制御性能を確認するために, Table 1 に 挙げる仕様を想定した.
Table 1 Building specification of MCE

\begin{tabular}{|l|rl|}
\hline Number of floors (excluding Garage Floor) & 30 \\
\hline Interfloor distance & $4.33 \mathrm{~m}$ \\
\hline Passenger boarding/alighting time & 1.2 & $\mathrm{~s} /$ person \\
\hline Door opening time & $1.8 \mathrm{~s}$ \\
\hline Door closing time & $2.4 \mathrm{~s}$ \\
\hline Rated speed & $6 \mathrm{~m} / \mathrm{s}$ \\
\hline Rated acceleration & $1.1 \mathrm{~m} / \mathrm{s}^{2}$ \\
\hline Jerk & $2.0 \mathrm{~m} / \mathrm{s}^{3}$ \\
\hline Capacity & 20 persons \\
\hline
\end{tabular}

\subsection{2 交通需要}

交通需要の発生はポアソン分布に従うものとし，出発階 と行先階の割合を表わす OD 表 ${ }^{10)}$ と, ビル全体の単位時間 当たりの乗客発生数とにより規定する. 乗客の OD 分布は 1 階から一般階 $(2$ 最上階 $)$ への交通量を $a$, 一般階から 1 階 への交通量を $b$, 一般階からほかの上方の一般階への交通量 を $c$, 一般階からほかの下方の一般階への交通量を $d$ とし,

$$
a: b: c: d=10: 10: 1: 1
$$

とした，乗客発生率については，軽負荷から重負荷まで MCE の挙動を分析する必要があるため，100人/時から 50 人/ 時ずつ増やしながら実験を行なった。

\section{2 .3 設備構成}

設備構成としてシャフト当たりのかご数 2 の MCEを考 え, シャフト数を $\{4,5,6\}$ と変化させて性能を評価した。 ま た, 比較のため, かご数 1 の従来型のエレベータについて は, シャフト数を $\{5,6,7,8,9,10,12\}$ と変化させて (注 1 ) 性能 を評価した。

以降, 設備構成をシャフト数 $x$ とシャフト当たりのかご 数 $y$ で表現し, $x \mathrm{~S} y \mathrm{C}$ と表記する.なお, $x \mathrm{~S} 1 \mathrm{C}$ は従来の工 レベータと同等である。

5.2 .4 制約条件

基本的制御性能の確認に際し，かご同士の衝突回避を行な うために以下の運行上の制約条件を設けた。

・同一シャフト内のかごは互いに向かい合う方向へは移動 できない。

・降下時に「下かご」はターミナル階に復帰後,「上かご」 がターミナル階に復帰するまでガレージ階で待機する。

5.2 .5 制御ルール

考察の対象とする制御ルールはホール呼びの発生時に乗客 の運搬を担当するかごを決定するアルゴリズムである。制 御ルールにおける決定事項は，各かごのサービスゾーンの 決定と, 乗客がホールボタンを押したときのその呼びへの かごの割当てルールからなる．まず，各かごのサービスゾー ンについては, サービスゾーンは予備的実験を踏まえて全 階床を等分に区切る形で設定した。つぎに，ホール呼びの 発生時にサービスを行なうかごの割当ての決定については， エレベータの状態から計算される各かごについてのいくつ

（注 1）一般には 8 シャフトを越えるエレベー夕群は使用されな いが，本論文では比較のために 9 シャフト以上も評価している。 
Table 2 Input signals at the time of allocation

\begin{tabular}{|l|l|}
\hline$v_{1}$ & estimated passenger's waiting time \\
$v_{2}$ & estimated passenger's waiting time increment for new \\
& hall call \\
$v_{3}$ & distance to new hall call \\
$v_{4}$ & estimated upper car's returning time increment for \\
& new call (if multicar) \\
$v_{5}$ & number of upward hall calls \\
$v_{6}$ & number of downward hall calls \\
$v_{7}$ & number of car calls \\
$v_{8}$ & sum of square number of upward hall calls in the cor- \\
$v_{9}$ & responding shaft (if multicar) \\
& sum of square number of downward hall calls in the \\
$v_{10}$ & distance to the nearest car in other shafts \\
$v_{11}$ & variance of distances between cars \\
\hline
\end{tabular}

かの属性值からなる属性值ベクトル $\boldsymbol{v}$ を用い, これと加重 值べクトルを $\boldsymbol{w}$ の内積で定義される評価值が最小となるか ごを割当てることとした，すなわち，サービスの候補となる かごを $c$ ，そのかごの属性值を $\boldsymbol{v}_{c}$, 割り当てられるかごを $c_{\text {allocate }}$ とすると,

$$
c_{\text {allocate }}=\arg \min _{c} \boldsymbol{w}^{T \cdot} \cdot \boldsymbol{v}_{c}
$$

である。

属性值ベクトル $\boldsymbol{v}$ では, 従来の群管理制御の知見を踏ま えて, Table 2 に挙げる 11 つの属性を正規化して用いた.

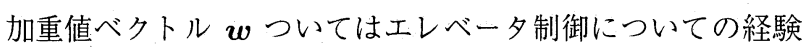
者が手作業で調整した。この方法で構成した制御ルールを CONTROLLER $R_{\text {proto, }}$ そのパラメータを $\boldsymbol{w}_{\text {proto }}$ と呼ぶ.

\subsection{MCE の性能確認}

シミュレーションでは，乗客の発生に乱数を用いる。 その ため, MCEの評価指標（たとえば平均待ち時間）の計測値 には，不確実なゆらぎが伴う，MCEについて，シャフト数 やかご数の構成間の比較はこのゆらぎを考慮して行なう必 要がある。そこで計測精度を高めるために，各構成に対し て共通の 10 種類の乱数系列を用いてシミュレーションを行 ない, 結果の平均值で性能評価を行なった，また，各シミュ レーションにおける初期の過渡状態を評価に含めないため に, シミュレーション時間で $1800 \mathrm{~s}$ から $5400 \mathrm{~s}$ の 60 分間に 発生した乗客について，それらの平均待ち時間を用いて評価 を行なった。

シミュレーションの結果について, 以下に挙げる項目につ いて確認および考察を行なう：

(1) MCE の輸送能力の限界.

(2) $\mathrm{MCE}$ の導入によるシャフト数削減の効果.

まず，乗客の輸送能力面での MCE の性能の限界について 確認を行なうため, 総かご数 $8,10,12$ の設備構成を持つ $\mathrm{MCE}(4 \mathrm{~S} 2 \mathrm{C}, 5 \mathrm{~S} 2 \mathrm{C}, 6 \mathrm{~S} 2 \mathrm{C})$ と, 従来のエレベータ $(8 \mathrm{~S} 1 \mathrm{C}$, $10 \mathrm{~S} 1 \mathrm{C} ， 12 \mathrm{~S} 1 \mathrm{C})$ の比較を行なった. シミュレーション結果 を Fig. 2〜4に示す. それぞれの構成について，一定の乗 客発生率を越えると平均待ち時間が指数関数的に悪化する

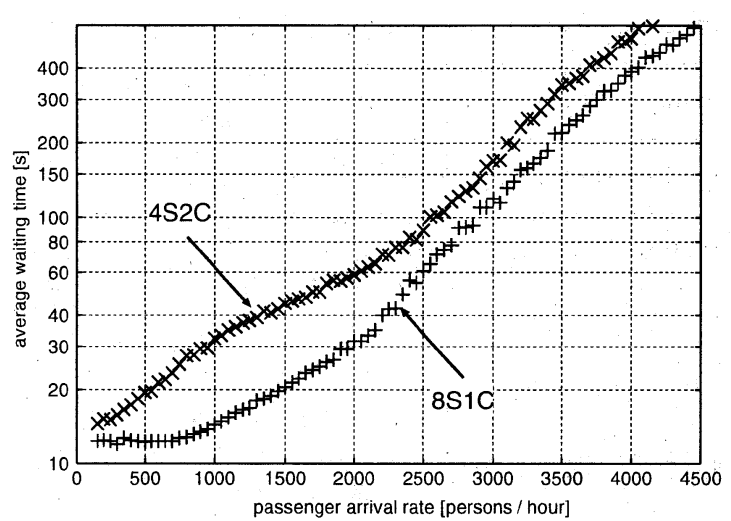

Fig. 2 Comparison between performances of $4 \mathrm{~S} 2 \mathrm{C}$ and $8 \mathrm{~S} 1 \mathrm{C}$

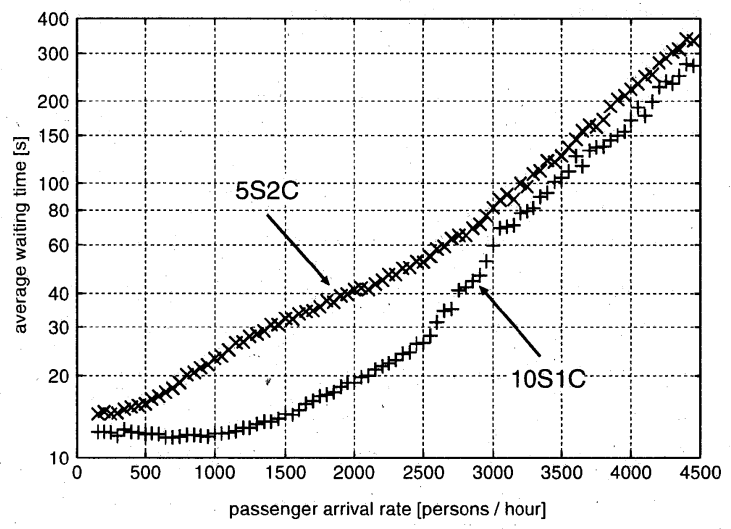

Fig. 3 Comparison between performances of 5S2C and 10S1C

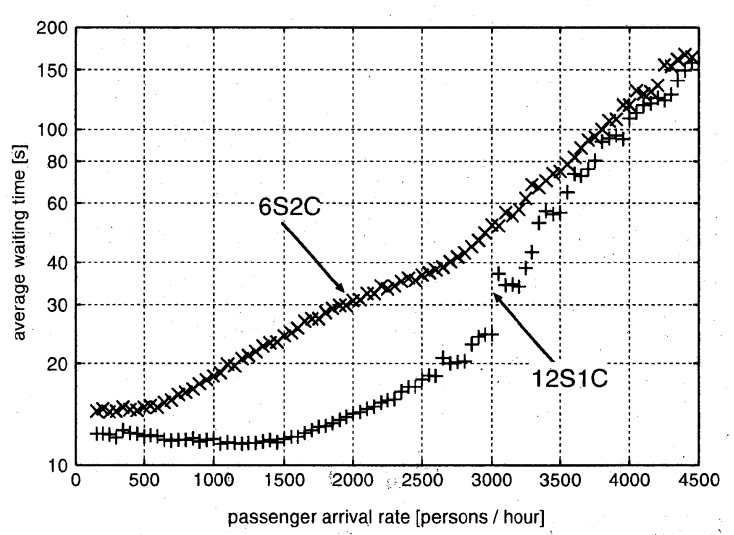

Fig. 4 Comparison between performances of $6 \mathrm{~S} 2 \mathrm{C}$ and $12 \mathrm{~S} 1 \mathrm{C}$

ことが確認される. MCEは同かご数（2 倍のシャフト数） を持つ従来のエレベータに比べ特に乗客発生数の小さい部 分で平均待ち時間が長い。しかし; 乗客発生率が大きくなる と，4S2C は $8 \mathrm{~S} 1 \mathrm{C} に ， 5 \mathrm{~S} 2 \mathrm{C}$ は $10 \mathrm{~S} 1 \mathrm{C}$ に $6 \mathrm{~S} 2 \mathrm{C}$ は $12 \mathrm{~S} 1 \mathrm{C}$ に性能が漸近する。このことから，総かご数が同等であれ 
Table 3 Effect of reduction of shafts by using MCE

\begin{tabular}{|c|c|c|c|}
\hline \multirow{2}{*}{ Passenger Arrival Rate } & \multirow{2}{*}{ Equipment } & \multicolumn{2}{|c|}{ Average Waiting Time } \\
\cline { 2 - 4 } & & ave. & std.dev. \\
\hline \multirow{2}{*}{1100 persons/hour } & $4 \mathrm{~S} 2 \mathrm{C}$ & $35.02 \mathrm{~s}$ & $1.55 \mathrm{~s}$ \\
\cline { 2 - 4 } & $5 \mathrm{~S} 1 \mathrm{C}$ & $37.02 \mathrm{~s}$ & $1.62 \mathrm{~s}$ \\
\hline \multirow{2}{*}{1200 persons/hour } & $5 \mathrm{~S} 2 \mathrm{C}$ & $26.42 \mathrm{~s}$ & $1.33 \mathrm{~s}$ \\
\cline { 2 - 4 } & $6 \mathrm{~S} 1 \mathrm{C}$ & $27.26 \mathrm{~s}$ & $1.51 \mathrm{~s}$ \\
\hline \multirow{2}{*}{1900 persons/hour } & $5 \mathrm{~S} 2 \mathrm{C}$ & $39.04 \mathrm{~s}$ & $1.98 \mathrm{~s}$ \\
\cline { 2 - 4 } & $7 \mathrm{~S} 1 \mathrm{C}$ & $39.74 \mathrm{~s}$ & $3.01 \mathrm{~s}$ \\
\hline \multirow{2}{*}{2000 persons/hour } & $6 \mathrm{~S} 2 \mathrm{C}$ & $30.79 \mathrm{~s}$ & $1.32 \mathrm{~s}$ \\
\cline { 2 - 4 } & $8 \mathrm{~S} 1 \mathrm{C}$ & $31.41 \mathrm{~s}$ & $2.15 \mathrm{~s}$ \\
\hline \multirow{2}{*}{2400 persons/hour } & $6 \mathrm{~S} 2 \mathrm{C}$ & $35.89 \mathrm{~s}$ & $1.90 \mathrm{~s}$ \\
\cline { 2 - 4 } & $9 \mathrm{~S} 1 \mathrm{C}$ & $32.18 \mathrm{~s}$ & $2.70 \mathrm{~s}$ \\
\hline \multirow{2}{*}{2700 persons/hour } & $6 \mathrm{~S} 2 \mathrm{C}$ & $40.12 \mathrm{~s}$ & $2.51 \mathrm{~s}$ \\
\cline { 2 - 4 } & $10 \mathrm{~S} 1 \mathrm{C}$ & $40.82 \mathrm{~s}$ & $7.58 \mathrm{~s}$ \\
\hline
\end{tabular}

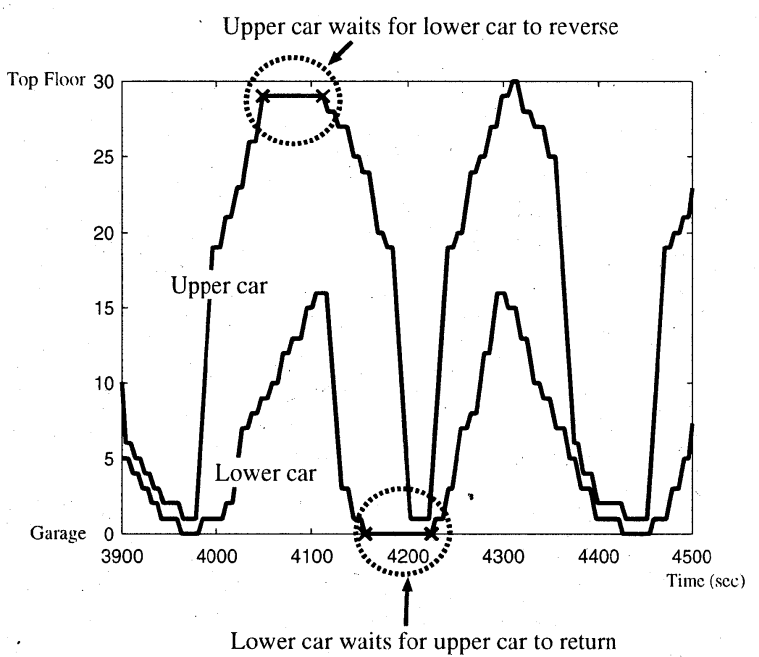

Fig. 5 A MCE travel diagram for 6S2C, 2700 persons/hour

ば, 輸送能力の限界も同等であることが確認される.

つぎに MCEの導入によるシャフト数削減の効果について 確認を行なうため, $4 \mathrm{~S} 2 \mathrm{C}, 5 \mathrm{~S} 2 \mathrm{C}, 6 \mathrm{~S} 2 \mathrm{C}$ の設備構成の $\mathrm{MCE}$ と従来のエレベータとの比較を Table 3 に示す。実際の エレベータの設計指針を考慮して, 乗客の平均待ち時間が $30 \mathrm{~s}$ から $40 \mathrm{~s}$ 程度になる乗客発生率を選び, 構成を比較する. Table 3 より 4S2C は 5S1Cに, 5S2C は 7S1Cに，6S2C は 9S1Cにそれぞれ性能が匹敵することが確認される。すなわ ち，超高層ビルではシャフトあたりに 2 台のかごを有する MCE を導入することで，ジャフト数を $30 \%$ 程度削減する ことが可能であり，ビル床面積の有効利用の観点から効果的 であることがわかる．また，平均待ち時間が同程度であれば マルチカー構成のほうが試行ごとの性能のばらつきが小さ くサービスがより安定することが期待できる.

\section{4 運行線図による MCE の動作の確認}

5.2 節で設定した制約条件の影響について検討するため に, MCEシミュレータが出力した運行線図の一例を Fig. 5 に示す、縦軸はがのの位置, 横軸はシミュレーション上の 時刻である．4100sでは下かごが上昇から下降に方向転換す るまで上かごが待機しており，4200sでは上かごが夕ーミナ
Table 4 CPU-time for a single simulation run

\begin{tabular}{|c|c|c|}
\hline \multirow{2}{*}{ Equipment } & \multicolumn{2}{|c|}{ Passenger Arrival Rate } \\
\cline { 2 - 3 } & 1300 persons/hour & 2700 persons/hour \\
\hline $4 \mathrm{~S} 2 \mathrm{C}$ & $11.73 \mathrm{~s}$ & $22.90 \mathrm{~s}$ \\
\hline $5 \mathrm{~S} 2 \mathrm{C}$ & $13.00 \mathrm{~s}$ & $27.10 \mathrm{~s}$ \\
\hline $6 \mathrm{~S} 2 \mathrm{C}$ & $14.13 \mathrm{~s}$ & $33.60 \mathrm{~s}$ \\
\hline
\end{tabular}

ル階に復帰するまで下かごがガレージ階で待機しているこ とが確認される.したがって，効率的な運行制御を行なうに は，これらの待避時間を減らすことが効果的である。

\section{5 シミュレーションの実行速度の確認}

シミュレーションの実行速度は, シミュレーションによる制 御ルールの評価や最適化を行なう際に実用的な評価可能回数 を決定する要因である。設備構成, 乗客発生率とシミュレー 夕の実行速度の関係を Table 4 に示す。これは Pentium3 $1.7 \mathrm{GHz}$ の CPU を搭載する計算機上で Java 言語の処理系 として Java 2 Platform Standard Edition (J2SE ${ }^{\mathrm{TM}}$ ) 1.3.1 を用いて実装したシミュレータにおいて，シミュレーション 時間で 5700s のシミュレーションを実行したときの CPU 時 間である．表より設備構成あるいは乗客発生率が大きくな ると, シミュレーションに要する時間は長くなることがわか る.また， 1 回のシミュレーションは $10 \mathrm{~s}$ から $30 \mathrm{~s}$ 程度要し ており, 最適化計算において評価回数を効果的に低減する必 要があることもわかる。

\section{6. 遺伝的アルゴリズムによる制御ルールの最適化}

\section{1 最適化の目的とその方法}

5.2 節で設定した制御ルールには属性間に相互依存性が存 在する。このため, 人手による加重值ベクトル $\boldsymbol{w}$ の最適な 調整は容易ではない，そこで本節では，遺伝的アルゴリズム (Genetic Algorithms，以下 GA と略す）を用いた加重值べ クトル $\boldsymbol{w}$ の最適化を試みた。最適化の検討は以下の手順で 行なう.

（1）最適化の対象となる交通需要, 設備構成の想定.

(2) 遺伝的アルゴリズムの実行.

(3) 最適化の効果の検討.

\section{2 最適化の対象の想定}

最適化の対象として $6 \mathrm{~S} 2 \mathrm{C}$ の設備構成で乗客発生率 2700 人/時を選んだ。これは平均待ち時間が $30 \mathrm{~s}$ から $40 \mathrm{~s}$ とな る実際的なエレベータの設計指針に基づいている，なお，仕 様，乗客発生分布，制約条件は 5.2 節と同じである。

\section{3 遺伝的アルゴリズムの実行}

GA は生物の進化過程をモデル化した確率的最適化手法で ある。GA は解候補の評価值のみを用いる手法であるため, 最適化対象に対する制限が少なく，シミュレーションを通じ た最適化においても利用が可能である。ただし，本問題では 以下の理由により, 従来の GA を適用すると, 評価が正し く行なわれずに学習速度が低下するだけでなく, 交通需要の 変化に対して頑健な最適解を獲得できない問題がある： 
Table 5 Configuration of Genetic Algorithm

\begin{tabular}{|l|l|}
\hline chromosome type & {$[-1,1]^{10}$} \\
fitness & average square waiting time \\
population size & 40 \\
children size & 6 \\
limit number of evaluation & 8000 \\
selection operation & tested-MFEGA \\
reproduction operation & UNDX ${ }^{11)}$ \\
mutation operation & none \\
\hline
\end{tabular}

・システムの評価に乱数を用いたシミュレーションを行な うため，得られる評価指標には不確実なゆらぎが伴う。

・シミュレーションに長い計算時間を要するため, 適応度 評価回数に制限がある.

・乱数系列を固定したシミュレーションのみを行なうと， 特定の乗客発生系列に特化した極端な解しか得られない 可能性がある.

上記の問題に対して, 探索履歴を参照して適応度を推定す ることでその不確実なゆらぎを低減し，より効率的で正確 な最適化を少ない評価回数で行なう GA（Memory-based Fitness Estimation GA: MFEGA) が佐野らによって提案 されており, ${ }^{1)}$ さらに同手法を改良した tested-MFEGA ${ }^{2)}$ が提案されている。本論文では交叉に $\mathrm{UNDX}^{11}$ （付録 A を 参照)，選択に tested-MFEGA（付録 B を参照，以下，簡単 のために MFEGA と呼ぶ）を適用し，Table 5 の設定で最 適化を実施した。なお，加重值べクトルは正の定数倍をし ても割当てるかごが変化しないという圥長性を持っている. そこで， $v_{1}$ への荷重 $w_{1}$ はその係数が正で良いことが予想 されるので值を 0.5 に固定し, ほかの要素は $w_{2}, \ldots, w_{11}$ の 初期值は $[-1,1]$ の一様分布にしたがって設定した.

また 5.5 節で示したとおり，この最適化対象では 1 回の シミュレーションに約 30 秒を要する。したがって, Table 5 に示した GAの実行には約 70 時間を要する。 そこで，本論 文では $8 \mathrm{CPU}$ からなる $\mathrm{PC}$ クラス夕を導入し，目的関数の 評価のみを並列化する master-slave 型 ${ }^{12)}$ の GA で高速化 を行ない, 最適化 1 試行に要する時間を約 10 時間に短縮し た。並列化の実現方法は文献 ${ }^{13)} て ゙$ 提案されており，その概 略を付録 Cで述べる。

\section{4 最適化の効果の検討}

Fig. 6 は GA10 試行での各世代における最優良個体の適 応度の推定值の最悪值, 平均值, 最良值の収束曲線である。 初期個体群の分布や適応度の評価に使用寸る乗客発生系列に 差異があるため，探索序盤の評価回数 400 回（第 45 世代） 付近までは試行ごとにばらつきが生じていることが確認さ れる。しかし，探索の進行と共に試行ごとのばらつきも小 さくなり，最悪值と最良值が漸近する。また同図では，適 応度は事前に計測した CONTROLLER proto $の 10$ 回平均 3570.30 より悪くなっている。これは探索序盤の悪い個体の 評価値が MFEGA の履歴に保持され，適応度の推定に使用 されているため，見かけ上，適応度の推定值が悪化すること

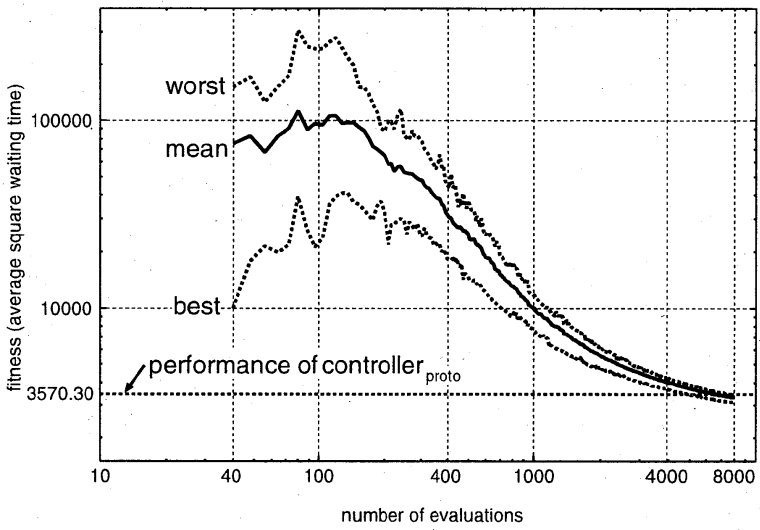

Fig. 6 The transition curve of the best of estimated fitness in a population (10 trials)

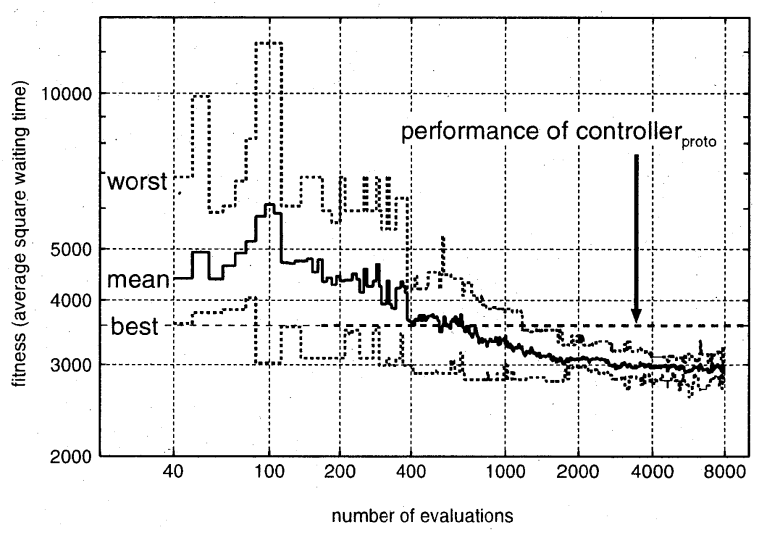

Fig. 7 Search precision (10 trials)

による。

そこで, MFEGA の探索精度を確認するために，乗客発 生系列に用いる乱数系列を共通にして，適応度の 10 回平均 を評価した。GA10 試行における各世代の最優良個体の最悪 值，平均值，最良值を Fig. 7 に示す. Fig. 6 と同様に探索 序盤は試行ごとにばらつきが生じていることと，探索の進行 とともにそれが小さくなり，適応度の改善も行なわれている ことが確認される．評価回数 2000 回（第 245 世代）以降は 最悪值についても CONTROLLER proto より良くなり, 評 価回数 4000 回（第 495 世代）以降は平均值，最悪值が，最 良值が 3000 付近で振動している，以上により，本問題でも 有効な最適化が行なわれ，試行によらず $\boldsymbol{w}_{\text {proto }}$ より優れ た加重值ベクトル $\boldsymbol{w}$ が発見されていることが確認される.

さらに，最適化で獲得した加重值ベクトル $\boldsymbol{w}_{\mathrm{opt}}$ が乗客発 生系列の変化に対する頑健性を検証するため, 試行回数 4000 回の時点における $\mathrm{GA} の$ 各試行での最優良個体について， Fig. 7 とは異なった乗客発生系列を用いて 100 回ずつ評価を 行なった. CONTROLLER $R_{\text {proto }}, C O N T R O L L E R_{\mathrm{opt}}$ の 平均 (標準偏差) は，それぞれ，3570.30（778.64）, 2915.50 (447.24) である.どの試行で得られた加重值べクトル 
$\boldsymbol{w}_{\mathrm{Opt}}$ も特定の乗客発生系列に過剩に適応しておらず，常に CONTROLLER proto より優れた性能を維持していること が確認される.

最後に，負荷の変化に対する頑健性を検証するため, 5.2 節と同様に, CONTROLLER $R_{\mathrm{Opt}}$ で 100 人/時から 50 人/ 時ずつ増やしながら性能の評価を行なった．結果を Fig. 8 に 示す. 乗客発生率が 500 人/時から 1500 人/時の低負荷で は CONTROLLER $\mathrm{opt}_{\text {ol }}$ の性能が CONTROLLER proto 比べて $2 \mathrm{~s}$ ほど平均待ち時間が悪化している。しかし，2700 人/時を越える高負荷では性能の改善が確認される。企 能は， 6 シャフトの MCE で 10 シャフトの従来のエレベー 夕以上の性能（Table 3 より）となっており, MCEの制御 ルールの最適化で輸送力の向上が可能であることが確認さ れた。

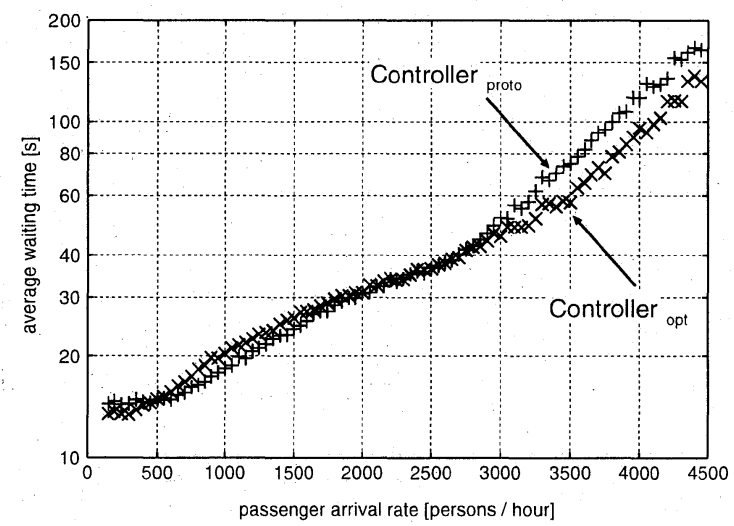

Fig. 8 Comparison between performance of prototype controller and optimized controller parameters

\section{7.おわりに}

本論文ではリニアモーターの利用を想定し，シャフト内 に複数のかごを有するマルチカーエレベータ (MCE)につい て，その運行制御を考察した。運行制御の開発手法としてシ ミュレーションベースの最適化を取り上げ，シミュレータの 構築と基本的な運行の評価を行ない, MCEの効果を確認す るとともに，遺伝的アルゴリズムによる割当てルールのパラ メータの最適化を行なった．最適化の結果, まず, 適応度の ゆらぎを考慮した遺伝的アルゴリズムである MFEGA が乗 客の発生系列にゆらぎのある, 試行回数に制限のある問題に 有効であることを確認した。また，高負荷において効率的な 割当てルールが形成され, システムの性能が向上することを 確認した。

\section{参 考 文 献}

1）喜多, 佐野：不確寒環境下での遺伝的アルゴリズム一応用の視 点から-, 電気制御学会論文誌, 121-C-6, 982/985 (2001)

2) Y. Sano and H. Kita: Optimization of Noisy Fitness Functions by means of Genetic Algorithms using History Search with Test of Estimation. Proc. of IEEE Congress of Evolutionary Computabion, 360/365 (2002)
3) ThyssenKrupp's TWIN Lift System Part One: The Introduction: Elevator World, 7, 51/53 (2003)

4）宮武, 古関, 曽根：ロープレスエレベータシステムの提案とそ の有効性評価, 電学論 D-199-11, 1353/1360 (1999)

5）吉田，藤河，志田，山田：ロープレスエレベータの最適制御 方式, 電気学会研究会資料, 産業計測制御研究会 2C-01-36, 61/66 (2001)

6) T. Sudo and S. Markon: The Performance of Multi-Car Linear Motor Elevators, Elevator Technology 11 Proceedings of ELEVCON 2001, 141/149 (2001)

7）小森谷, 喜多, Markon, 西川：自律分散型超高層ビル内搬送シ ステムのためのエージェント間協調手法の検討, 計測自動制御 学会論文集 36-12, 1152/1161 (2000)

8) K. Mimaki, S. Markon, H. Kita, Y. Komoriya and Y. Nishikawa: Modeling and Analysis of Complex Traffic in Buildings, Proc. IEEE SMC' 99, IV, 589/594 (1999)

9) Jonathan S. Ostroff: Temporal Logic for Real-time Systems, Research Studies Press (1989)

10）佐佐木, 飯田：交通工学, オーム社 (1995)

11) I. Ono and S. Kobayashi: A Real-coded Genetic Algorithm for Function Optimization Using Unimodal Normal Distribution Crossover, Proc. 7th ICGA, 246/253 (1997)

12) Erick Cantü-Paz: Efficient and Accurate Parallel Genetic Algorithms, 33/47, Kluwer Academic Publishers (2000)

13）高橋, 喜多, 鈴木, 須藤, Markon：PC クラス夕を用いたマル チカー制御方法の最適化, SICE 第 15 回自律分散シンポジウ ム, $1 / 6(2003)$

\section{《付 録》}

\section{A. 単峰性正規分布交叉 UNDX ${ }^{11)}$}

単峰性正規分布交叉 (Unimodal Normal Distribution Crossover, 以下 UNDX と略す) は, 実数值遺伝的アルゴ リズムにおいて, 多峰性関数や変数間の依存関係の強い関数 を考慮した交叉方法である。

UNDX は子個体を第 1 親 $\boldsymbol{P}_{1}$ および第 2 親 $\boldsymbol{P}_{2}$ の重心 $\boldsymbol{m}$ の周囲に正規分布を用いて生成する．正規分布の標準偏 差を決定するために第 3 親 $\boldsymbol{P}_{3}$ を補助的に用いる。生成さ れる子個体べクトル $\boldsymbol{C}_{1}, \boldsymbol{C}_{2}$ は，以下の式にしたがって決 定される：

$$
\begin{aligned}
& \boldsymbol{C}_{1}=\boldsymbol{m}+\left(z_{1} \boldsymbol{e}_{1}+\sum_{k=2}^{n} z_{k} \boldsymbol{e}_{k}\right) \\
& \boldsymbol{C}_{2}=\boldsymbol{m}-\left(z_{1} \boldsymbol{e}_{1}+\sum_{k=2}^{n} z_{k} \boldsymbol{e}_{k}\right)
\end{aligned}
$$

ただし, $n$ は次元数, $z_{1} \sim N\left(0, \sigma_{1}^{2}\right)$ と $z_{k} \sim N\left(0, \sigma_{2}^{2}\right)(k=$ $2, \ldots, n)$ は，標準偏差 $\sigma_{1}=\alpha d_{1} ， \sigma_{2}=\beta d_{2} / \sqrt{n}$ に従う正 規乱数である。ここで, $d_{1}$ は $\boldsymbol{P}_{1}$ と $\boldsymbol{P}_{2}$ の距離, ベクトル $\boldsymbol{e}_{1}$ は $\boldsymbol{P}_{1}$ と $\boldsymbol{P}_{2}$ を結ぶ主探索方向の単位ベクトル, $d_{2}$ は $\boldsymbol{P}_{3}$ から $\boldsymbol{P}_{1}$ と $\boldsymbol{P}_{2}$ を結ぶ軸までの距離, $\boldsymbol{e}_{k}(k=2, \ldots, n)$ は $e_{1}$ に直交する部分空間の正規直交基底である.

\section{B. tested-MFEGA ${ }^{2)}$}

$\mathrm{MFEGA}^{1)}$ は不確実性を伴う適応度関数を最適化するた めに，探索履歴を用いて確率モデルのパラメータと適応度を 推定して淘汰を行なう GAである。

MFEGA で適応度を推定する際,「興味の対象とする探索 点の周辺の適応度関数值は, 探索点での真の適応度関数値を 中心に正規分布にしたがって分布する」という確率モデルを 
導入する. そして, 正規分布の分散は探索点 $x$ からの距離 $d$ に比例していると仮定する。すなわち，

$$
\begin{aligned}
& f(\boldsymbol{h}) \sim N(f(\boldsymbol{x}), k d) \\
& F(\boldsymbol{h})=f(\boldsymbol{h})+\delta \sim N\left(f(\boldsymbol{x}), k d+\sigma^{2}\right)
\end{aligned}
$$

ここで $f(x)$ は $\boldsymbol{x}$ での真の適応度関数值, $k$ は個体間距離 への係数である.また，適応度の確率分布は正規分布である と仮定する。個体の真の適応度の推定值は最尤法により,

$$
\tilde{f}(\boldsymbol{x})=\frac{F(\boldsymbol{x})+\sum_{l=2}^{H} \frac{1}{\left(k^{\prime} d_{l}+1\right)} F\left(\boldsymbol{h}_{l}\right)}{1+\sum_{l=2}^{H} \frac{1}{\left(k^{\prime} d_{l}+1\right)}}
$$

と得られる。ここで探索履歴中の $\mathrm{H}$ 個の個体を $\boldsymbol{h}_{l}, l=$ $1, \ldots, H$ とし,$F\left(\boldsymbol{h}_{l}\right)$ と $d_{l}, l=1,2, \ldots, H$ をそれらの観測 された適応度関数值と探索点 $\boldsymbol{x}$ からの距離とする。また， $k^{\prime}=k / \sigma^{2}$ である。

tested-MFEGA $^{2)}$ は MFEGA の改良で, 探索履歴が希溥 な領域に有望な個体が生成されたとき，適応度の誤推定によ り淘汰されることを防ぐために，サンプル值について Z 検 定を行ない，探索精度の向上を図った MFEGA である。

\section{PC クラスタによる master-slave 型の GA の} 実現方法

GA による個体の評価はほかの個体に独立であるため，並 列化が容易で，計算時間を短縮することが可能である。こ の種の最適化に対して効果的な並列化手法が提案されてお り ${ }^{13)}$ ，その概略を下記に示す：

パラメトリックタスクの支援 パラメトリックタスクとは特 定のパラメータだけを変えながら同じタスクを繰り返し 実行する計算処理である。たとえば，GAに㧈ける個体群 の評価はパラメトリックタスクの1つである。この並列 化手法にはプログラム作成を支援するインタフェイスを実 装している.

クライアントノサーバシステム構成 クライアントは評価 を依頼する master-slave 型の master 側，サーバは評価 を実行して結果を返す master-slave 型の slave 側である。 パラメトリックタスクを効率的に実行するためにシミュ レーションの設定情報などサーバはパラメータ以外の情報 を保持し，通信量の削隇を行なう。

逐次スケジューリング 評価を実行しているサーバから結 果を受け取り次第，クライアントはそのサーバにつぎの夕 スクを投入する逐次的なスケジュール方法を用いた。この 方法は夕スクの割り当てを決定するために要するコスト が小さく，同等の計算能力を持つ計算機群でパラメトリッ クタスクを並列化する際に有効である。

タイムアウトによる障害検出 ホストおよび通信経路の障 害はタイムアウトにより検出する．ユーザは並列化を行な う前にタスク当たりの実行時間を見積もり，タイムアウト 時間を設定する。なお，障害が生じたと判定された場合，
実行中であったタスクは別のサーバを代替サーバとして再 実行する。

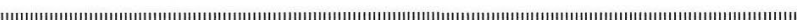

$$
\text { [著者紹介] }
$$

鈴 木 裕 通

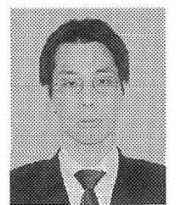

2000 年東京工業大学工学部情報工学科卒業。 2002 年同大学大学院総合理工学研究科知能シス テム科学専攻修士課程修了．同年よりフジテック （株）に勤務。

\section{高 橋 聡}

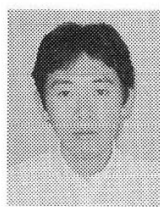

2001 年電気通信大学電子工学科卒業. 2003 年 東京工業大学大学院総合理工学研究科知能シス テム科学専攻修士課程修了。同年より富士重工業 （株）に勤務。

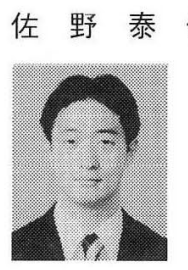

1998 年東京農工大学工学部機械システム工学 科卒業. 2003 年東京工業大学大学院総合理工学 研究科知能システム科学専攻博士課程修了。同年 より日産自動車 (株) に勤務. 博士 (工学).

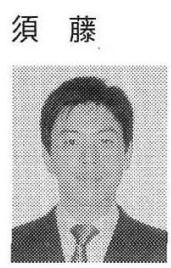

1997 年京都大学工学部建築学第二学科卒業. 99 年京都大学大学院工学研究科生活空間学専攻修了. 同年よりフジテック(株) に勤務。

マルコン シャンドル

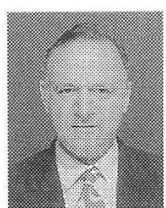

1973 年ハンガリー・ブタペスト工科大学電気工 学科卒業. 同年ハンガリー Ganz Electric Works 社に勤務. $75 \sim 77$ 年京都大学研究生. 79 年フジ テック（株）に入社し現在に至る. 博士 (工学). システム解析, シミュレーション, ニューラルネッ 卜に関する研究などに従事。JNNS，INNSなど の会員.

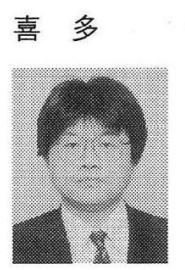

- (正会員)

1982 年, 京都大学工学部電気工学科卒業, 87 年同大学院工学研究科博士後期課程研究指導認定 退学. 同年京都大学工学部助手, 97 年より東京工 業大学大学院総合理工学研究科助教授, 2001 年 大学評価・学位授与機構教授を経て, 2003 年よ り京都大学学術情報メデイアセンター教授となり, 現在に至る. 工学博士. 社会・エネルギーシステ ム，ニューラルネットワーク，遺伝的アルゴリズ ムの研究に従事.システム制御情報学会, 電子情 報通信学会, 日本 OR 学会などの会員。

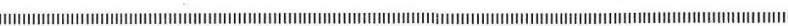

